\title{
The Portrayal of Birth and Death in Kieslowski's "Dekalog"
}

\author{
Sofia Gourgoulianni \\ Adjunct Faculty, Department of Computer Science \\ University of Thessaly, Papasiopoulou, 2-4, 35100 \\ Galaneika, Lamia
}

\begin{abstract}
Krzystof Kieslowski has undoubtedly been one of the great directors of the $20^{\text {th }}$ century. Even though he began directing films with direct political dimension, he was later on drawn to the metaphysics of human relations as the basic subject of his filmography. In 1989 he prepared a series for the polish television with the ten independent episodes, entitled "Dekalog" and inspired from the "Ten Commandments". The series consists of ten deeply humane stories and is considered as an artistic monument of Kieslowski's basic problematic over the metaphysics of human relations. As each human life and relation begins with birth and ends with death, we have chosen to examine the way birth and death are treated in Kieslowski's "Dekalog" and the symbolisms they entail in each different episode.
\end{abstract}

Keywords: Dekalog, Kieslowski, Birth, Death

Krzystof Kieslowski, who unfortunately died at the age of 54, as at trace of his artistic grandeur, has bequeathed to the art of cinema his own exquisite voyeuristic look at human relations. However, even though he seems to lean on man and observe his everyday life with the outmost detail in order to seek pleasure and artistic beauty, Kieslowski never reveals whether he holds the role of the doctor or the patient, the sadist or the masochist, the perpetrator or the victim. This happens probably because the essence of art is skillfully trampled between pain and pleasure and its' ultimate goal is to bond bidirectionally the public and the creator.

Kieslowski although a pioneer of the famous Cinema of Moral Anxiety, which condemned the abuses of dysfunctional communism, quickly abandoned direct political cinema for the sake of the metaphysics of human relations. As far as the Dekalog is concerned, Celeste (2004) states: "The questions of freedom, authority and the undecideability of the law have been staples of the Polish diet. Kieslowski's refusal of an interpretation of the Dekalog as a metaphor for a political subtext says a lot about the tragic ambitions of this cinema and the difficulty of justice today". As Kieslowski (1993) has himself declared, "the ten films of the Dekalog are not political". It is therefore clear that, by creating the " Dekalog ", Kieslowski managed to transform simple dilemmas of human relations into ecumenical questions. Metaphysics' central questions, "what is there?" and "what does it look like?" is at the center of the mystery of human relations and at the core of Kieslowskis' questioning. However, even though it seems a purely theoretical problematic, it is closely linked to the basic practical subject of human life. According to Kickasola (2016), Kieslowski's Dekalog idealizes the Ten Commandments through living people and it is not always happy, easy or completely perceivable. And as human life is always finite and bonded with birth and death, Kieslowski's art is equally concerned by the theme of its beginning and ending. Without making any exception, the "Dekalog" places the different shades of birth and death at the center of its cinematographic universe.

In view of the above, the purpose of this article is to present the ten episodes of Kieslowski's Dekalog and discuss the way they portray the themes of birth and death.

Episode 1 - I am the Lord thy God; thou shalt have no other God but me.

A lake in a Polish city freezes and a father's computer calculates that it will not crack. The son owns a brand new pair of ice skates and regards the lake as an ideal skating opportunity. The computer in the role of "god" proves to be inadequate, the lake fragile and the son dead.

In this case, the lives of the son and the father are bonded to the outmost point, as the mother is dead. However, even though they seem to lead normal and happy lives, their existence is haunted by the death of the mother. Moreover, the house they live in, as a modern Canterville mansion, seems to be invaded by her spirit. With its fatal and tragic ending, the death of the son, this episode points out that life and death exist in an unavoidable sequence.

Episode 2 - Thou shalt not take the name of the Lord thy God in vain

An elderly doctor, permanently morose, is visited by a young neighbor who informs him that her husband is a patient in the clinic in which he works. She demands of the doctor to take the role of god, by asking him to decide with 
certainty whether the husband will survive or not. When the doctor refuses to answer directly, his wife reveals that she is carrying the child of another man. And that if her husband survives she will terminate the pregnancy. In this case, there is an unborn human being which carries the sperm of a future death, this one of the woman's husband. It is a child who was "planted" in life when its supposed father was struggling to be kept in life. In this case, Kieslowski, puts death and life in balance. And although life triumphs here, as both the husband and the child survive, its victory is phyrric and temporary.

Episode 3 - Remember the sabbath day, to keep it holy

During Christmas Eves' night, a man, a taxi driver, delivers gifts to his family. When the phone rings, his ex-mistress informs him that her husband is missing and he spontaneously rushes to help her. The plot of this episode is unfolded during a night in a desperate search for the possibly dead husband, a haunting ghost which reunites and twists both the lives of the ex-lovers.

Here, death, even though it is not certain, is depicted as fatal and ominous. Moreover, it is presented as capable of demolishing conventional happiness and opening the door to disastrous passion. In this case, passion is depicted as the only antidote to the certainty of the future death. As Kieslowski himself explained, in an interview with journalists 'Man does not choose between good and evil. He chooses between lesser and greater evil' (Turaj 1998). In Episode Three the protagonists do not surrender to their desires and in the end the woman admits that she was lying throughout the night and that her husband has been absent already for three years. Moreover, she accepts the fact that she was searching of a means to spend the night of Christmas Eve with her former lover. In this case, death in its true sense is not to be found, however, the episode is all about the symbolic death of passion and the return to conventional happiness.

Episode 4 - Honour thy father and thy mother

Young Anka attends a dramatic school and lives with her father. Her mother is dead since her childhood, and a relationship of dependence is created between the father and the daughter throughout the years. When the father leaves on a few days journey, Anca will discover a sealed letter from the mother, with the footnote, "To be opened after my death". During the fathers' absence, Anka hesitates between opening and not opening the letter. When, finally, she opens it, the letter reveals to her that the man she grew up with, is not her father. Afterwards, their relationship seems to take a painful twist.

In this case, the death of the mother emphatically highlights its "presence", creating dependencies and bonds that are depicted as insoluble. In reality, the daughter and the father are in constant search of happiness which can, however, only exist as common. However, even though the death of the mother is depicted as a tragic incident, the birth of the daughter created new life and extremely fluid social roles between the two members of the family.

Episode 5 - Thou shalt not kill

Two deaths in a dynamic cinematographic manifesto against the "man-eating" character of murder.

A young man with criminal tendencies, murders in cold bold and total consciousness, a taxi driver whose works and days were consumed in "teasing" young women and in terrorizing innocent dogs with a gun and with the sound of his horn. The young man is given a lawyer for his defense, who proves to be equally young and also sensitive and idealistic. Therefore, even though the lawyer's intentions were good, his young age, sensitivity, and immature ideas were not proved adequate for the defense of the young man. As a consequence, the young man is driven, cynically and inexorably, to death penalty.

Kieslowski, here, does not ask questions, but he admits the universal injustice of murder. Life is the ultimate common good which is destined to be removed only by human fortune and not by mans' own hands.

Episode 6 - Thou shalt not commit adultery

A story about all those different versions of love which are destined to destroy the cliché of Hollywood romance. If "Pretty Woman" and the movies of its kind, talk about "pretty" loves, which "live happily ever after", Kieslowski pulls out of the wardrobe self-destructive and voyeuristic love. A young man, in a long time platonic love with his polygamous neighbor, puts on his binoculars and watches her in her every day, erotic or not, activities. When he, finally, finds the courage to approach her, his act will prove fatal as he will attempt suicide. And if love borders with voyeurism, Kieslowski asks us to realize that eventually the insatiable love for cinema can also be based on the irresistible human tendency of consuming other peoples' lives.

Episode 7- Thou shalt not steal

A different version of Madam Bovary in 1989 by Krzysztof Kieslowski. 
A 22-year-old woman had given birth to the fruit of her love with a professor at her 16th birthday. In an attempt to "wipe out" the scandal, as a blood stain on a tissue, the mother of the 16 year old recognized the new born child as her own.

Six years later, with her maternal instinct fleeing violently from hibernation, the young real mother, in search of her own byronic passions, kidnapped her daughter by deciding to create a common future for the two of them. And if Flaubert's heroine actually landed in a stifling marriage, Kieslowski's feminine heroine opened her wings to a sky that eventually "offered" her hail. So when the blessing of her bond with the child turns out to be a burden, the disillusioned hasty escape will be the only entrance to a world of freedom.

Episode 8 - Thou shalt not bear false witness against thy neighbour

In the idiosyncratic Kieslowskian dialect, the years of innocence may not possess the cinematographic words to be printed on paper or projected on screen, but they have, eventually, been already buried forever. In this case, in the role of the cat, we meet a young Polish-American Jewish researcher, and in the role of the mouse, a middle-aged teacher. When the young woman visits Poland, she encounters, with her fingernails sharpened, the teacher. And she tells her that she has deprived her of her childhood innocence when she refused to host her as a child in her home during the Second World War.

As an atonement against the blame, the middle-aged man will reveal that she sacrificed one life, the young Jew, in a desperate attempt to save many lives. At that time, the permanently Sisyphean task, this of the answer to the question of the individual sacrifice in the name of the collective "good" will come violently to the surface. In this episode, Kieslowski will look hard at us by asking us to take a position he has already decided, that we rightfully own and have to take completely individually.

Episode 9 - Thou shalt not covet thy neighbour's wife

A man is suddenly confronted with permanent sexual impotence and urges his wife to find a lover. When he realizes that he cannot remain abreast with his decision, the self-destructive monster of jealousy rises. Another story for the hard face of love and all those secrets buried under tons of everyday life. And for which, just a single flam suffices to wake them out of a dream of utopian happiness. Kielsowki, in this case, delivers a story about the death of love and the power that its inevitable ending has on man's life. Both the protagonists seem to try to find the everyday moments which will revive their past relationship. However, when love finally dies, it drifts their lives with the power of its ending.

Episode 10 - Thou shalt not covet thy neighbour's goods

Keeping the surprise of changing his dramatic tone for his last episode, in this episode Kieslowski delivers an intelligent black comedy Two brothers inherit from their father a valuable collection of stamps. When a truly rare stamp will prove to be absent from the collection, the price to obtain it will rise to the kidney of one of the two siblings. However, in the world of Kieslowski, King Midas who turned into gold anything he touched and into happiness every tragedy, has long died. And, because, eventually, Murphy's law has taken the place of the king, the descent will prove to be immediate and violent. By using the humor which transforms the blackness of tragedy into the gray of parody, Kieslowski, here, captures in his cinematographic hands all those dreams which seem to look like huge balloons that, however, deflate in just one second.

\section{Conclusion}

By recounting ten different stories of human relationships, Kieslowski studies at the same time the different shades of birth and death. Although birth, for the rest of the world, generates happy smiles and promises for brilliant future, Kieslowski regards it as just another event lost in the eternal sequence of moments. As far as death is concerned, Kieslowski, by totally avoiding any melodramatic tone, treats death, not as a resounding tragedy, but as a tacit acceptance of an unavoidable vicious circle.

\section{References}

Reni, C. (2004). Decalogue: Poland's cinema of collision, Studies $\quad$ in $\quad$ European Cinema, 1:3, 175184. DOI: $10.1386 /$ seci.1.3.175/0

Kieslowski, K. (1993). Kieslowski on Kieslowski, in Danusia Stok (ed.). Boston: Faber, p. 144.

Kickasola, J.G. (2016). Tablets of Stone, Tablets of Flesh: Synesthetic Appeal in The Decalogue, in Badowska \& Parmegianni (eds), Of Elepahants and Toothaches, Ethics Politics and Religion in Krzystof Kieslowski's Decalogue (15-30). New York: Fordham University Press.

Turaj, K. (1998). Greatness Set in Stone. Los Angeles Times, 1 November, p. 39. 